\title{
EVALUASI LAPORAN AKUNTABILITAS KINERJA INSTANSI PEMERINTAH PADA SATUAN KERJA NON VERTIKAL TERTENTU PENYEDIAAN PERUMAHAN PROVINSI SULAWESI UTARA
}

\author{
Kezia Princesa Wantah ${ }^{1}$, Lintje Kalangi ${ }^{2}$, Steven Tangkuman ${ }^{2}$ \\ ${ }^{1,2}$ Jurusan Akuntansi, Fakultas Ekonomi dan Bisnis, Universitas Sam Ratulangi, Jl. Kampus Bahu, Manado, \\ 95115, Indonesia \\ ${ }^{1}$ E-mail: keziaawantah@gmail.com
}

\begin{abstract}
LAKIP is the government's accountability for activities carried out within one budget year and as one of the realization of good governance. The community questioned whether the budget used was appropriate or not with what they received.In addition, accountability reports on public sector organizations are only oriented to "output" rather than "outcome". This resulted public sector organizations to pay more attention to value for money that is able to consider inputs, outputs, especially outcomes that underlie the three main elements namely economy, efficiency and effectiveness.This study aims to find out how the SNVT Provision program in North Sulawesi Province is measured using the concept of value for money.The research method used is descriptive qualitative with the results of interviews and data collected, analyzed and conclusions drawn.The results showed that the evaluation of the SNVT program for the Provision of Housing in the Province of North Sulawesi was measured by the concept of value for money for economic measurements achieving good results. However, the measurement for efficiency and effectiveness are not yet optimum as the budget is not fully realized.
\end{abstract}

Keywords: LAKIP; value for money; economy; efficiency; effectiveness

\section{PENDAHULUAN}

Pemerintahan yang bersih (good governance) dilandasi oleh 3 (tiga) pilar utama yang saling berkaitan, yaitu partisipasi, transparansi dan akuntabilitas. Suatu pemerintahan yang baik sebaiknya melibatkan semua pihak yang terkait dalam pemerintahan agar dapat berperan serta atau berpartisipasi secara aktif sehingga roda pemerintahan dapat diselenggarakan secara transparan dan dapat dipertanggungjawabkan. Pemerintah menerbitkan TAP MPR RI Nomor XI/MPR/1998 tentang penyelenggaraan negara yang bersih dan bebas korupsi, kolusi, dan nepotisme, serta Undang-Undang Nomor 28 Tahun 1999 untuk mewujudkan tata kelola pemerintahan yang baik. Sebagai tindak lanjut dari produk hukum tersebut maka diterbitkanlah Instruksi Presiden Republik Indonesia Nomor 7 tahun 1999 tentang akuntabilitas kinerja instansi pemerintah. Akuntabilitas kinerja instansi pemerintah merupakan perwujudan kewajiban instansi pemerintah untuk mempertanggungjawabkan keberhasilan dan kegiatan pelaksanaan misi organisasi dalam mencapai sasaran dan tujuan yang telah ditetapkan melalui sistem pertanggungjawaban secara periodik.

Akuntabilitas dalam sektor publik dapat digambarkan sebagai hubungan antara pemerintah dan masyarakat, dimana pemerintah berfungsi sebagai agen yang diberi kewenangan untuk melaksanakan kewajiban yang ditentukan masyarakat sebagai prinsipal, baik secara langsung maupun tidak langsung dan hanya diwakilkan. Akuntabilitas yang dimaksudkan adalah kemampuan untuk menunjukkan bagaimana pertanggungjawaban segala aktivitas dan terhadap kinerja finansial apakah sudah ekonomis, efisiensi dan efektif (value for money) melalui pengukuran kinerja. Pengukuran kinerja sangat penting untuk menilai akuntabilitas organisasi sektor publik dalam menghasilkan pelayanan publik yang lebih baik. 
Hasil dari pengukuran kinerja sektor publik ini pada akhirnya harus dilaporkan dalam bentuk laporan pertanggungjawaban kinerja sebagai pedoman bagi pemerintah daerah untuk mengelola keuangan daerah pada masa yang akan datang dan juga sebagai alat pengawasan bagi masyarakat terhadap kebijakan yang telah dipilih atas pelaksanaan anggaran daerah.

Berdasarkan Peraturan Presiden Republik Indonesia Nomor 29 Tahun 2014 maka Sistem Akuntabilitas Kinerja Instansi Pemerintah (SAKIP) adalah merupakan rangkaian sistematik dari berbagai aktivitas, alat, dan prosedur yang dirancang untuk tujuan penetapan dan pengukuran, pengumpulan data, pengklasifikasian, pengikhtisaran, dan pelaporan kinerja pada instansi pemerintah dalam rangka pertanggungjawaban dan peningkatan kinerja instansi pemerintah. Laporan Akuntabilitas Kinerja Instansi Pemerintah (LAKIP) merupakan akhir dari pelaksanaan SAKIP yang menggambarkan kinerja yang dicapai oleh suatu instansi pemerintah atas pelaksanaan program dan kegiatan yang dibiayai APBN/APBD. Pertanggungjawaban dan pelaporan segala aktivitas instansi pemerintah baik pusat maupun daerah dituangkan dalam LAKIP.

Seiring perkembangan teknologi informasi, kinerja sebuah instansi pemerintah banyak menjadi perhatian publik dimana masyarakat umum masih memiliki persepsi bahwa instansi pemerintah belum memiliki kinerja yang optimal dan cenderung memiliki potensi inefisiensi dan potensi penyimpangan atas pemanfaatan dan penggunaan dana publik. Berdasarkan persepsi publik ini, maka instansi pemerintah melakukan perbaikan berkelanjutan dengan memperhatikan value for money yang mempertimbangkan input, output dan outcome. Value for money adalah konsep pengelolaan instansi pemerintah yang didasarkan pada 3 (tiga) elemen utama, yaitu ekonomi, efisiensi dan efektivitas. Ekonomi merupakan hal yang terkait dengan sejauh mana organisasi sektor publik dalam hal ini Satuan Kerja Non Vertikal Tertentu Penyediaan Perumahan Provinsi Sulawesi Utara dapat meminimalisir input resources yang digunakan untuk menghindari inefisiensi. Efisiensi merupakan pencapaian output yang maksimum dengan input tertentu atau pengguna input yang terendah untuk mencapai output tertentu. Efektivitas yaitu tingkat pencapaian hasil program dengan target yang ditetapkan, atau secara sederhana merupakan perbandingan outcome dengan output. Melalui metode value for money diharapkan instansi pemerintah dapat mengukur dan mengevaluasi kinerja dalam suatu periode tertentu dan meminimalisir pemborosan dan potensi penyimpangan.

Satuan Kerja Non Vertikal Tertentu (SNVT) Penyediaan Perumahan Provinsi Sulawesi Utara bertujuan untuk membantu Kementerian Pekerjaan Umum dan Perumahan Rakyat Republik Indonesia dalam seluruh pelaksanaan program perumahan di Indonesia agar semakin cepat dan baik serta lebih meningkatkan koordinasi antara pusat dan daerah. SNVT Penyediaan Perumahan Provinsi Sulawesi Utara memiliki misi meningkatkan kualitas dan kuantitas lingkungan perumahan dan permukiman, meningkatkan atau mempercepat ketersediaan sarana dan prasarana, dan meningkatkan pendayagunaan sumber daya perumahan secara optimal. SNVT Penyediaan Perumahan Provinsi Sulawesi Utara wajib melaporkan setiap pertangunggjawaban terhadap pelaksanaan kinerjanya yang telah dilakukan ke dalam LAKIP yang disampaikan setiap akhir tahun anggaran. Laporan tersebut menguraikan tingkat capaian kinerja baik keberhasilan maupun kendala semua program dan kegiatan yang telah dilaksanakan. Salah satu permasalahan dalam pengukuran kinerja LAKIP adalah pelaksanaan program yang masih berorientasi pada "output" daripada "outcome". SNVT Penyediaan Perumahan Sulawesi Utara masih memiliki laporan akuntabilitas kinerja yang berorientasi luaran (ouput) daripada hasil (outcome) dimana indikator program yang dicapai belum menunjukkan hasil (outcome) yang optimal. Hal ini menunjukkan bahwa kinerja SNVT Penyediaan Perumahan Provinsi Sulawesi Utara masih menitikberatkan pada realisasi penuh atas anggaran atau tahap pelaksanaan program dan belum sepenuhnya mempertimbangkan optimalisasi relevansi dengan kebutuhan masyarakat. 
LAKIP SNVT Penyediaan Perumahan Provinsi Sulawesi Utara tahun 2018 memuat pelaksanaan 3 (tiga) program kegiatan, yaitu: (1) penyusunan perencanaan penyediaan perumahan; (2) pemberdayaan perumahan swadaya; dan (3) penyediaan rumah khusus dan rumah susun. Secara ideal, pelaksanaan ketiga program kerja tersebut diharapkan mampu menerapkan metode value for money dengan mempertimbangkan input, output, dan outcome sehingga pelaporan atas program kerja tidak hanya terbatas pada luaran (output) tetapi juga memiliki hasil/dampak (outcome) pada kesejahteraan masyarakat.

\section{TINJAUAN PUSTAKA}

Akuntansi sektor publik. Menurut Ratmono (2015:2), akuntansi sektor publik dapat diartikan sebagai proses pengidentifikasian, pengukuran, pencatatan, dan pelaporan transaksi keuangan dari entitas pemerintah daerah dalam rangka pengambilan keputusan ekonomi yang diperlukan oleh pihak eksternal. Sujarweni (2015:17) menyatakan bahwa akuntansi sektor publik adalah salah satu ilmu akuntansi yang digunakan untuk perusahaan nirlaba, seperti akuntansi pemerintahan, akuntansi rumah sakit, akuntansi pendidikan, akuntansi yayasan, dan akuntansi organisasi nirlaba lainnya.

Akuntansi pemerintahan. Menurut Peraturan Pemerintah Nomor 24 tahun 2005, sistem akuntansi pemerintahan adalah serangkaian prosedur manual maupun yang terkomputerisasi mulai dari pengumpulan data, pencatatan, pengikhtisaran, dan pelaporan posisi keuangan dan operasi keuangan pemerintah. Sadeli (2015:6) menunjukkan bahwa akuntansi pemerintahan termasuk pula akuntansi lembaga-lembaga non profit (institusional accounting) yang mengkhususkan pada masalah pencatatan dan pelaporan transaksi dari unitunit pemerintah dan organisasi non profit lainnya, seperti: masjid, lembaga amal, yayasan, rumah sakit, dan lembaga-lembaga pendidikan.

Akuntabilitas. Menurut Djalil (2014:63), akuntabilitas merupakan suatu konsep etika yang begitu dekat dengan administrasi publik pemerintahan (lembaga eksekutif pemerintah, lembaga legislatif parlemen, dan lembaga yudikatif) yang mempunyai beberapa arti, seperti dipertanggungjawabkan (responsibility), yang dapat dipertanyakan (answerbility), yang dapat dipersalahkan (blameworthiness), dan yang mempunyai keterkaitan dengan harapan yang dapat menerangkan salah satu aspek dan administrasi publik pemerintah. Mahsun (2016:169) menyatakan bahwa akuntabilitas dapat dipahami sebagai kewajiban pihak pemegang amanah untuk memberikan pertanggungjawaban, menyajikan, melaporkan, dan mengungkapkan segala aktivitas dan kegiatan yang menjadi tanggungjawabnya kepada pihak pemberi amanah yang memiliki hak dan kewenangan untuk meminta pertanggungjawaban tersebut. Menurut Lukito (2014:2), akuntabilitas adalah bentuk kewajiban penyelenggara kegiatan publik untuk dapat menjelaskan dan menjawab segala hal menyangkut langkah dari seluruh keputusan dan proses yang dilakukan, serta pertanggungjawaban kinerjanya.

Pengukuran kinerja. Gobel dan Koton (2016:11) menyatakan bahwa pengukuran kinerja merupakan suatu proses penilaian kemajuan pekerjaan terhadap pencapaian tujuan dan sasaran yang telah ditentukan, termasuk informasi atas efisiensi penggunaan sumber daya dalam menghasilkan barang jasa, kualitas barang dan jasa, perbandingan hasil kegiatan dengan target, dan efektivitas tindakan dalam mencapai tujuan.

Tujuan dan indikator pengukuran kinerja. Menurut Mardiasmo (2018:152), tujuan sistem pengukuran kinerja, yaitu: (1) mengkomunikasikan strategi secara lebih baik; (2) mengukur kinerja finansial dan non finansial secara berimbang sehingga dapat ditelusuri perkembangan dan pencapaian strategi; (3) mengakomodasi pemahaman kepentingan manajer level menengah dan bawah serta memotivasi untuk mencapai goal congruence; dan (4) sebagai alat untuk mencapai kepuasan berdasarkan pendekatan individual dan kemampuan kolektif yang rasional. Menurut Indra Bastian dalam Rahajeng (2018), indikator kinerja adalah ukuran kuantitatif dan kualitatif yang menggambarkan tingkat pencapaian 
sasaran atau tujuan yang telah ditetapkan dengan memperhitungkan indikator masukan (input), keluaran (output), hasil (outcome), manfaat (benefits) dan dampak (impacts).

Laporan Kinerja Instansi Pemerintah (LAKIP). Laporan Kinerja Instansi Pemerintah merupakan produk akhir dari Sistem Akuntabilitas Kinerja Instansi Pemerintah yang menggambarkan kinerja yang dicapai oleh suatu instansi pemerintah atas pelaksanaan program dan kegiatan yang dibiayai APBN/APBD. Tiap informasi yang termuat dalam LAKIP dapat dimanfaatkan untuk perbaikan kinerja instansi secara berkesinambungan. Sukarno et al. (2020) menemukan bahwa LAKIP adalah penjabaran pertanggungjawaban dan gambaran kinerja instansi yang bertujuan untuk menghasilkan laporan kinerja yang merepresentasikan keberhasilan dan kegagalan misi dan sasaran organisasi secara periodik. LAKIP harus menyajikan data dan informasi relevan bagi pembuat keputusan agar dapat menginterpretasikan keberhasilan dan kegagalan secara lebih luas dan mendalam. Oleh karena itu, perlu dibuat suatu analisis tentang pencapaian akuntabilitas kinerja instansi secara keseluruhan. Penyusunan LAKIP harus dilandasi dengan pengertian dan kesadaran bahwa laporan akan dapat bermanfaat bagi terwujudnya pemerintahan yang baik, bersih, dan produktivitas di lingkungan instansi pemerintah.

Value for money. Menurut Arisaudi (2016), value for money merupakan tolak ukur dari pengukuran kinerja pada organisasi pemerintah yang didasarkan pada ukuran ekonomis, efisiensi, dan efektivitas. Sedangkan menurut Halim dan Kusufi (2014:128), value for money merupakan konsep untuk mengukur ekonomi, efisiensi dan efektivitas kinerja program, kegiatan dan organisasi, yaitu ekonomi terkait sejauh mana organisasi sektor publik meminimalisir input resource yang digunakan yaitu dengan menghindari pengeluaran yang boros dan tidak produktif, efisiensi terkait pencapaian output yang maksimum dengan input tertentu atau penggunaan input yang terendah untuk mencapai output tertentu dan efektivitas tingkat pencapaian hasil program dengan target yang ditetapkan.

Pengukuran ekonomi. Menurut Mahmudi dalam Syadiyah et al. (2016), pengukuran ekonomis dapat dinyatakan dengan rasio input atas harga input dan diukur dengan persen. Kriteria penilaian tingkat ekonomis adalah: (a) jika diperoleh nilai perbandingan lebih dari $100 \%$ maka ekonomis; (b) jika diperoleh nilai sama dengan 100\% maka ekonomis berimbang; dan (c) jika diperoleh nilai kurang dari 100\% maka tidak ekonomis.

Pengukuran efisiensi dan efektivitas. Menurut Mardiasmo (2018:167), pengukuran efisien dapat dinyatakan dengan rasio output atas input dan diukur dengan persen. Kriteria penilaian tingkat efisiensi adalah: (a) jika diperoleh nilai perbandingan lebih dari $100 \%$ maka efisien; (b) jika diperoleh nilai sama dengan 100\% maka efisien berimbang; dan (c) jika diperoleh nilai kurang dari 100\% maka tidak efisien. Menurut Mardiasmo (2018:168), efektivitas adalah ukuran berhasil tidaknya suatu organisasi mencapai tujuannya dimana suatu organisasi atau program dapat dinilai efektif apabila output yang dihasilkan memenuhi tujuan yang diharapkan.

\section{METODE PENELITIAN}

Penelitian ini menggunakan pendekatan kualitatif dengan menerapkan metode analisis deskriptif dimana jenis data yang digunakan adalah data kuantitatif berupa realisasi anggaran dan data kualitatif berupa dokumen LAKIP SNVT Penyediaan Perumahan Provinsi Sulawesi Utara Tahun 2018. Sumber data penelitian ini bersifat primer yang diperoleh secara langsung dari hasil observasi lapangan pada SNVT Penyediaan Perumahan Provinsi Sulawesi Utara dengan cara wawancara secara langsung mengenai profil organisasi, struktur organisasi, dan dokumen yang berupa LAKIP serta laporan realisasi anggaran. 


\section{HASIL PENELITIAN DAN PEMBAHASAN}

\subsection{Hasil penelitian}

SNVT Penyediaan Perumahan Provinsi Sulawesi Utara melaksanakan 3 (tiga) program kegiatan pada tahun 2018 dan penelitian ini mengukur tingkat ekonomis, tingkat efisiensi, dan tingkat efektivitas 3 (tiga) program tersebut berdasarkan indikator kinerja yang diuraikan berikut.

1. Program Penyusunan Perencanaan Penyediaan Perumahan

Input : Dana

Output : Terlaksananya pendataan Rumah Tidak Layak Huni (RTLH) serta jumlah backlog perumahan di Sulawesi Utara.

Outcomes: Tercapainya backlog dalam rangka perencanaan kegiatan di bidang perumahan, serta pendataan inventarisasi aset yang ada di Sulawesi Utara.

2. Program Pemberdayaan Perumahan Swadaya

Input : Dana

Output : Pelaksanaan pembangunan atau pembaharuan peningkatan kualitas rumah di bidang perumahan swadaya.

Outcomes : Dapat membantu masyarakat yang berpenghasilan rendah yang rumahnya sudah tidak layak untuk dihuni.

3. Program Penyediaan Rumah Khusus dan Rumah Susun

Input : Dana

Output : Terlaksananya pembangunan rumah khusus di 2 (dua) lokasi yaitu di Kabupaten Minahasa Selatan dan Kabupaten Bolaang Mongondow serta rumah susun di Kota Manado.

Outcomes : Dapat membantu masyarakat yang tidak memilik rumah atau tempat tinggal tetap.

\subsection{Pembahasan}

Pengukuran ekonomi. Pengukuran ekonomi dikatakan ekonomis apabila organisasi sektor publik mampu menghilangkan atau mengurangi biaya-biaya yang tidak perlu. Semakin kecil nilai dari rasio ekonomi, maka semakin baik kinerja SNVT Penyediaan Perumahan Provinsi Sulawesi Utara dalam program penyusunan perencanaan penyediaan perumahan, program pemberdayaan perumahan swadaya, dan program penyediaan rumah khusus dan rumah susun. Tabel 1 menunjukkan tingkat ekonomis program kerja berdasarkan kinerja SNVT Penyediaan Perumahan Provinsi Sulawesi Utara.

Tabel 1. Pengukuran tingkat ekonomis

\begin{tabular}{lrcc}
\hline \multicolumn{1}{c}{ Program } & \multicolumn{1}{c}{ Realisasi } & \multicolumn{1}{c}{ Target } & Tingkat Ekonomis \\
\hline Penyusunan Perencanaan Penyediaan Perumahan & 3.062 .847 .000 & 3.158 .000 .000 & $96,99 \%$ \\
Pemberdayaan Perumahan Swadaya & 67.431 .364 .000 & 67.623 .000 .000 & $99,72 \%$ \\
Penyediaan Rumah Khusus dan Rumah Susun & 46.791 .849 .000 & 46.836 .000 .000 & $99,91 \%$ \\
\hline
\end{tabular}

Sumber: Data olah, 2020

Pengukuran efisiensi. Pengukuran efisiensi dikatakan efisien apabila pencapaian nilai output lebih besar dibandingkan dengan nilai input. Kinerja SNVT Penyediaan Perumahan Provinsi Sulawesi Utara terhadap program penyusunan perencanaan penyediaan perumahan, program pemberdayaan perumahan swadaya, dan program penyediaan rumah khusus dan rumah susun dikatakan efisien jika nilai yang dihasilkan adalah lebih dari $100 \%$. Semakin besar nilai efisiensi maka semakin baik kinerja keuangan SNVT Penyediaan Perumahan Provinsi Sulawesi Utara. Tabel 2 menunjukkan tingkat efisiensi program kerja berdasarkan kinerja SNVT Penyediaan Perumahan Provinsi Sulawesi Utara. 
Tabel 2. Pengukuran tingkat efisiensi

\begin{tabular}{lccc}
\hline \multicolumn{1}{c}{ Kegiatan } & Output & Input & Tingkat Efisiensi \\
\hline Penyusunan Perencanaan Penyediaan Perumahan & $97 \%$ & $96,99 \%$ & $100,01 \%$ \\
Pemberdayaan Perumahan Swadaya & $98 \%$ & $99,72 \%$ & $98,28 \%$ \\
Penyediaan Rumah Khusus dan Rumah Susun & $99 \%$ & $99,91 \%$ & $99,09 \%$ \\
\hline
\end{tabular}

Sumber: Data olah, 2020

Pengukuran efektivitas. Pengukuran efektivitas ini pencapaian hasil program dengan tujuan yang ditetapkan dengan membandingkan antara outcome dan output. Pada umumnya, pengukuran ini sangat sulit karena outcome tidak bisa dikuantifikasikan. Suatu program dinilai efektif apabila output yang dihasilkan memenuhi tujuan yang diharapkan. Untuk pengukuran efektivitas, penelitian ini menggunakan hasil wawancara dengan beberapa pegawai SNVT Penyediaan Perumahan Provinsi Sulawesi Utara mengenai ketiga program kegiatan yang telah dilaksanakan yaitu program penyusunan perencanaan penyediaan perumahan, program pemberdayaan perumahan swadaya, dan program penyediaan rumah khusus dan rumah susun.

Hasil pengukuran value for money pada Program Penyusunan Perencanaan Penyediaan Perumahan. Hasil pengukuran value for money pada program kegiatan penyusunan perencanaan penyediaan perumahan oleh SNVT Penyediaan Perumahan Provinsi Sulawesi Utara menunjukkan bahwa pengukuran ekonomi masih mencapai kriteria tidak ekonomis dan pengukuran efisien telah mencapai kriteria efisien. Pencapaian tingkat efisiensi disebabkan SNVT Penyediaan Perumahan Provinsi Sulawesi Utara mampu meminimalisir dana yang digunakan untuk program ini. Program kegiatan ini memiliki nilai anggaran sebesar Rp 3.158.000.000 dengan realisasinya sebesar Rp 3.062.847.000 sehingga hal ini menunjukkan bahwa dalam pelaksanaaan program ini, SNVT Penyediaan Perumahan Provinsi Sulawesi Utara mampu meminimalisir dana yang digunakan yaitu dengan menghemat biaya sebesar Rp 95.153.000. Pengukuran efektivitas dalam program penyusunan perencanaan penyediaan perumahan dilakukan dengan metode wawancara dimana metode ini dilakukan untuk melihat apakah program kegiatan ini sudah memenuhi tujuannya atau tidak. Berdasarkan hasil wawancara, program penyusunan perencanaan penyediaan perumahan SNVT Penyediaan Perumahan Provinsi Sulawesi Utara telah terlaksana dengan baik dan efektif karena telah memenuhi tujuannya.

Hasil pengukuran value for money pada Program Pemberdayaan Perumahan Swadaya. Hasil pengukuran value for money pada program kegiatan pemberdayaan perumahan swadaya oleh SNVT Penyediaan Perumahan Provinsi Sulawesi Utara menunjukkan bahwa pengukuran ekonomi masih menunjukkan kriteria tidak ekonomis. Belum optimalnya tingkat ekonomis disebabkan SNVT Penyediaan Perumahan Provinsi Sulawesi Utara menganggarkan program ini sebesar Rp 67.623.000.000 dengan realisasi sebesar Rp 67.431.364.000 dimana hasil pengukuran ekonominya mencapai 99,72\%. SNVT Penyediaan Perumahan Provinsi Sulawesi Utara meminimalisir dana yang digunakan untuk program ini dengan penghematan sebesar Rp 191.636.000 namun pengukuran efisiensi masih menunjukkan capaian yang belum optimal karena hanya mencapai 98,27\% sedangkan tingkat efisiensi disebut optimal jika mencapai lebih dari 100\%. Pengukuran efektivitas dalam program pemberdayaan perumahan swadaya dilakukan dengan metode wawancara untuk melihat apakah program kegiatan ini sudah memenuhi tujuannya atau tidak. Pada tahun anggaran 2018, SNVT Penyediaan Perumahan Provinsi Sulawesi Utara memiliki target untuk menuntaskan pelaksanaan pembangunan peningkatan kualitas rumah swadaya dimana pembangunan fisik telah mencapai $100 \%$ namun dalam penyerapan anggaran belum mencapai $100 \%$ yang disebabkan kendala dari beberapa keluarga calon penerima bantuan 
sehingga anggaran tersebut dikembalikan ke kas negara. Hasil ini menunjukkan bahwa kegiatan pemberdayaan rumah swadaya belum efektif dalam pencapaian tujuan.

Hasil pengukuran value for money pada Program Penyediaan Rumah Khusus dan Rumah Susun. Hasil pengukuran value for money pada program kegiatan penyediaan rumah khusus dan rumah susun oleh SNVT Penyediaan Perumahan Provinsi Sulawesi Utara menunjukkan bahwa pengukuran ekonomi masih mencapai kriteria tidak ekonomis. Belum optimalnya tingkat ekonomis disebabkan SNVT Penyediaan Perumahan Provinsi Sulawesi Utara menganggarkan program ini sebesar Rp 46.836.000.000 dengan realisasi sebesar Rp 46.791.849.000 dimana hasil pengukuran ekonomi hanya mencapai 99,91\%. SNVT Penyediaan Perumahan Provinsi Sulawesi Utara meminimalisir dana yang digunakan untuk program ini dengan penghematan sebesar $\mathrm{Rp} 44.151 .000$ namun hasil pengukuran masih menunjukkan capaian yang belum optimal atau tidak efisien karena tingkat efisiensi hanya mencapai 99,09\% sedangkan tingkat efisiensi adalah optimal jika mencapai lebih dari $100 \%$. Pengukuran efektivitas dalam program penyediaan rumah khusus dan rumah susun dilakukan dengan metode wawancara untuk melihat apakah program kegiatan ini sudah memenuhi tujuannya atau tidak. Berdasarkan hasil wawancara, program penyediaan rumah khusus dan rumah susun telah mencapai tujuan karena telah merealisasi pembangunan rumah khusus berjumlah 100 unit yaitu di Kabupaten Minahasa Selatan sebanyak 50 unit dan Kabupaten Bolaang Mongondow sebanyak 50 unit. Selain itu, pencapaian lainnya adalah realisasi pembangunan rumah susun di Kota Manado sebanyak 1 (satu) tower untuk ASN Pemerintah Provinsi Sulawesi Utara, sebanyak 1 (satu) tower untuk mahasiswa IAIN Kota Manado, dan sebanyak 1 (satu) tower untuk pekerja di Kabupaten Minahasa sehingga program penyediaan rumah khusus dan rumah susun dari SNVT Penyediaan Perumahan Provinsi Sulawesi Utara dapat disebut baik dan efektif karena telah memenuhi tujuannya.

\section{KESIMPULAN DAN SARAN}

\subsection{Kesimpulan}

Berdasarkan hasil evaluasi data LAKIP terhadap penilaian kinerja pada ketiga program kegiatan SNVT Penyediaan Perumahan Provinsi Sulawesi Utara dengan menggunakan konsep value for money, maka dapat disimpulkan bahwa: (1) Program Kegiatan SNVT Penyediaan Perumahan di tahun 2018 belum ekonomis karena mencapai nilai kriteria dibawah $100 \%$ yang menunjukkan bahwa SNVT Penyediaan Perumahan Provinsi Sulawesi Utara belum optimal memanfaatkan dana dalam melaksanakan programprogramnya walaupun tidak melakukan pengeluaran biaya-biaya yang tidak perlu; (2) Program Kegiatan SNVT Penyediaan Perumahan Provinsi Sulawesi Utara di tahun 2018 belum sepenuhnya dinyatakan efisien karena program pemberdayaan perumahan swadaya dan program penyediaan rumah khusus dan rumah susun masih berada dibawah 100\%; dan (3) Program Kegiatan SNVT Penyediaan Perumahan Provinsi Sulawesi Utara di tahun 2018 dapat dinyatakan sudah efektif untuk program penyusunan perencanaan penyediaan perumahan dan program penyediaan rumah khusus dan rumah susun sedangkan program pemberdayaan perumahan swadaya dapat dinyatakan belum efektif. Hal ini menunjukkan bahwa SNVT Penyediaan Perumahan Provinsi Sulawesi Utara perlu memperhatikan outcomes dari suatu program yang akan dilaksanakan walaupun program tersebut sudah terlaksana dengan baik.

\subsection{Saran}

Saran atas penelitian ini adalah agar SNVT Penyediaan Perumahan Provinsi Sulawesi Utara perlu memperhatikan capaian tingkat ekonomis, tingkat efisiensi, dan tingkat efektivitas atas program kerja yang direncanakan dan dapat menghindari biaya-biaya yang belum diperlukan. 


\section{DAFTAR PUSTAKA}

Arisaudi, Z. (2016). Analisis pengukuran kinerja pelaksanaan anggaran belanja dengan value for money pada Dinas Pekerjaan Umum Bina Marga dan Pengelolaan Sumber Daya Air Kota Palembang. Skripsi. Universitas Muhamadiyah, Palembang, Indonesia. http://repository.um-palembang.ac.id/id/eprint/1334/

Djalil, R. (2014). Akuntabilitas keuangan daerah implementasi pasca reformasi. Jakarta: RM Books.

Halim, A., \& Kusufi, M. S. (2014). Teori, konsep, dan aplikasi akuntansi sektor publik, Edisi 2. Jakarta: Salemba Empat.

Instruksi Presiden Republik Indonesia Nomor 7 Tahun 1999 tentang akuntabilitas kinerja instansi pemerintah.

Ketetapan Majelis Permusyawaratan Rakyat Republik Indonesia Nomor XI/MPR/1998 tentang penyelenggara negara yang bersih dan bebas korupsi, kolusi, dan nepotisme.

Lukito, P. K. (2014). Membumikan transparansi dan akuntabilitas kinerja sektor publik: Tantangan berdemokrasi ke depan. Jakarta: Grasindo.

Mahsun, M. (2016). Pengukuran kinerja sektor publik. Yogyakarta: BPFE-Yogyakarta.

Mardiasmo. (2018). Akuntansi sektor publik. Yogyakarta: Andi.

Peraturan Pemerintah Nomor 24 Tahun 2005 tentang Standar Akuntansi Pemerintah (SAP).

Peraturan Presiden Nomor 29 Tahun 2014 tentang Sistem Akuntabilitas Kinerja Instansi Pemerintah.

Rahajeng, A. D. (2018). Analisis pengukuran kinerja organisasi sektor publik dengan pendekatan value for money (Studi kasus di Dinas Pendidikan Kabupaten Sleman). Skripsi. Universitas Sanata Dharma, Yogyakarta, Indonesia. https://repository.usd.ac.id/27247/2/142114023_full.pdf

Ratmono, D. (2015). Akuntansi keuangan daerah berbasis akrual, Edisi Kedua. Yogyakarta: UPP STIM YKPN.

Sadeli, L. M. (2015). Dasar-dasar akuntansi, Edisi Pertama. Jakarta: Bumi Aksara.

Sujarweni, V. W. (2015). Akuntansi sektor publik. Yogyakarta: Pustaka Baru Press.

Sukarno, A. S., Tinangon, J. J., \& Tangkuman, J. S. (2020). Pengaruh kompetensi aparat dan komitmen organisasi terhadap implementasi sistem akuntabilitas kinerja instansi pemerintah (Studi pada Kantor Perwakilan Badan Pengawasan Keuangan dan Pembangunan Provinsi Sulawesi Utara). Indonesia Accounting Journal, 2(2), 110117. https://doi.org/10.32400/iaj.27981

Syadiyah, K., Susanti, W., \& Rasyidi, A. (2016). Analisis value for money dalam pengukuran kinerja keuangan pada Badan Penanggulangan Bencana Daerah Kabupaten Sidoarjo. $\begin{array}{llll}\text { E-Journal Akuntansi "EQUITY", } & \text { 2(4), }\end{array}$ http://fe.ubhara.ac.id/ojs/index.php/equity/article/view/192

Gobel, E. Z., \& Koton, Y. P. (2016). Pengelolaan Danau Limboto dalam perspektif kebijakan publik. Yogyakarta: Penerbit CV Budi Utama. 